\title{
Investigations on the Action of the Iron-Containing Growth Factors, Sideramines; and Iron-Containing Antibiotics, Sideromycins
}

\author{
BY B. F. BURNHAM* \\ Microbiology Unit, Department of Biochemistry, University of Oxford
}

(Received 11 December 1962)

\begin{abstract}
SUMMARY
The formation of catalase activity by an Arthrobacter strain JG-9 is dependent upon the addition of exogenous haemin, or the iron-containing growth factor ferrichrome. The iron-containing antibiotic ferrimycin A inhibited the synthesis of catalase in bacterial suspensions supplemented with ferrichrome, but did not measurably alter catalase formation in suspensions supplemented with haemin. This suggests that ferrichrome is necessary for haemin (catalase) synthesis, and that ferrimycin $\mathrm{A}$ acts by blocking this step. Cell-free extracts of Rhodopseudomonas spheroides were able to synthesize haemin when incubated with an oxidizable substrate, protoporphyrin IX and iron supplied as ferrichrome.
\end{abstract}

\section{INTRODUCTION}

During the last 10 years a series of naturally occurring iron-binding compounds possessing potent biological activity has been discovered (Hesseltine et al. 1952; Neilands, 1952; Lochhead, Burton \& Thexton, 1952; Bickel et al. 1960). The only feature common to all these compounds is that the iron-binding structure is in each case a secondary hydroxamic acid (Emery \& Neilands, 1959; Bickel et al. 1960). Biologically the compounds seem to fall into two groups: growth factors and antibiotics. One biological characteristic common to all the compounds is that they are extremely potent: e.g. the growth factor ferrichrome supports half maximal growth of Arthrobacter JG-9 at a concentration of $0.3 \mathrm{~m} \mu \mathrm{g} . / \mathrm{ml}$., and the antibiotic ferrimycin $\mathbf{A}$ is ten times as active as penicillin on a weight basis against Bacillus subtilis.

Bickel and co-workers have observed that with certain bacteria these ironcontaining antibiotics and iron-containing growth factors are mutually antagonistic (Bickel et al. 1960; Zähner, Hütter \& Bachmann, 1960). They proposed the generic name siderochrome to include all naturally occurring iron-binding hydroxamic acids. Those compounds which have antibiotic activity they called sideromycins, and those capable of antagonizing sideromycins were classed as sideramines (Bickel et al. 1960). The distinction between these two types of iron-binding compounds becomes less clear when they are examined for growth-factor activity against certain bacteria. Arthrobacter terregens, Arthrobacter JG-9, and Arthrobacter flavescens are representative organisms which have a growth-factor requirement satisfied by haemin or a naturally occurring hydroxamic acid (Burnham \& Neilands,

* Present address: The Charles F. Kettering Research Laboratory, Yellow Springs, Ohio. 
1961), and with these organisms the sideromycins are about as effective as sideramines in promoting growth (author's unpublished results). It seems likely that such micro-organisms have lost not only the ability to synthesize sideramines, but have also lost much of their specificity for the siderochrome necessary to replace the natural sideramine. Under these circumstances, the loss of specificity would have survival value. Recent work on the metabolic function of ferrichrome provided evidence that this compound directly influences the ability of Arthrobacter JG-9 to incorporate iron into protoporphyrin (Burnham, 1962). In the present paper additional evidence for the participation of ferrichrome in the synthesis of haemin is presented, and a possible site of action of the sideromycins is suggested.

The design of the experiments was based on the observations of Zähner et al. (1960) that the antibiotic action of the sideromycins could be countered by the sideramines. Instead of using growth inhibition to measure antagonism, however, the ability of the test bacteria to synthesize catalase in the presence of sideramines and sideromycins was studied. Ferrichrome was chosen as the representative sideramine, and ferrimycin $\mathbf{A}$ was chosen as representative sideromycin. The test micro-organism was Arthrobacter JG-9, whose growth-factor requirement can be satisfied by ferrichrome or by ferrimycin A. However, the organism does display specificity to the extent that, when grown in the presence of one of these compounds, it will not respond to the other for a period of several hours, and for a short time the compounds are antagonistic in the classical manner. Since the antagonistic period is short, and since the growth rate is slow, it is generally not possible to observe an effect upon growth.

Previously it was shown that the amount of catalase in the organism, measured as catalase activity/mg. dry wt., provided a very sensitive index to the state of ferrichrome nutrition of Arthrobacter JG-9 (Burnham \& Neilands, 1961). In ferrichrome-deficient organisms, the catalase content decreased before growth was measurably affected, and the synthesis of new catalase was apparent before growth recommenced after providing growth factor. Similarly, with organisms treated with ferrichrome and ferrimycin $\mathbf{A}$, it was possible to measure an effect on catalase synthesis under conditions where growth was not measurably affected.

\section{METHODS}

Organisms. Arthrobacter strain JG-9, a ferrichrome-requiring bacterium, was originally obtained from Dr H. A. Barker, and has been described previously (Burnham \& Neilands, 1961; Greenberg \& Barker, 1962). The photosynthetic bacterium Rhodopseudomonas spheroides, and a streptomycin-resistant variant of Staphylococcus aureus, strain SG 511 var, which requires haemin for growth, were both obtained from Dr June Lascelles (Oxford). These organisms were grown under conditions described previously by Lascelles $(1956 a, b)$.

Chemicals. Ferrichrome was obtained from iron-deficient Ustilago sphaerogena fermentations as described previously by Neilands (1952). Ferrimycin A was generously donated by Dr E. Vischer (Ciba Ltd., Basle). Protohaemin IX was purchased from Schuchardt and Co. (GmbH, Munich, Germany) and was recrystallized three times from glacial acetic acid before use.

Determination of haemin. Haemin was measured by the very sensitive nitrate reductase assay with Staphylococus aureus, as developed by Lascelles (1956b). 
Assay of catalase activity. The catalase activity of washed cell suspensions was measured by the colorimetric titanium sulphate method described by Weil-Malherbe \& Schade (1948).

\section{RESULTS}

\section{Antagonism experiments}

The organism Arthrobacter JG-9 was grown for about $48 \mathrm{hr}$. in the usual medium (Burnham \& Neilands, 1961) at a ferrichrome concentration of $1 \mathrm{~m} \mu \mathrm{g} . / \mathrm{ml}$. Under these conditions, growth was limited and the catalase activity of the organisms very low. The organisms were harvested by centrifugation and divided into 6 portions for subsequent treatments. Ferrichrome, ferrimycin $\mathrm{A}$ and haemin were added singly and in admixtures to these suspensions.

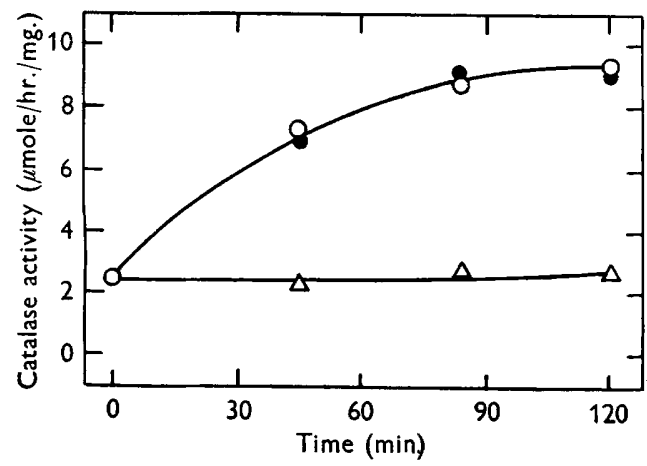

Fig. 1

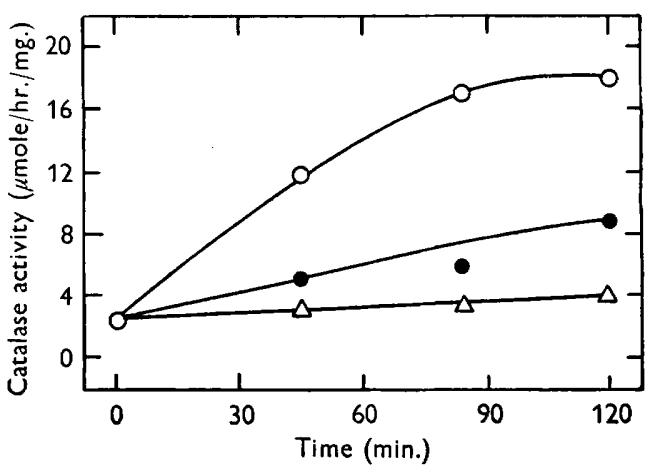

Fig. 2

Fig. 1. Increase in catalase activity after adding haemin and ferrimycin $A$ to a ferrichrome-deficient culture of Arthrobacter JG-9. The organism was grown in basal medium + ferrichrome to $1 \mathrm{~m} \mu \mathrm{g}$. $/ \mathrm{ml}$. After $48 \mathrm{hr}$. at $30^{\circ}$ the organisms were harvested by centrifugation and resuspended at a concentration equiv. $0.5 \mathrm{mg}$. dry wt. organism $/ \mathrm{ml}$. in media as follows : 0 , basal medium $+100 \mathrm{~m} \mu \mathrm{g}$. haemin $/ \mathrm{ml}$; 9 , basal medium $+100 \mathrm{~m} \mu \mathrm{g}$. haemin $/ \mathrm{ml}$. $+200 \mathrm{~m} \mu \mathrm{g}$. ferrimycin A/ml.; $\triangle$, basal medium $+200 \mathrm{~m} \mu \mathrm{g}$. ferrimycin $\mathrm{A} / \mathrm{ml}$.

Fig. 2. Increase in catalase activity after adding ferrichrome and ferrimycin $A$ to a ferrichrome-deficient culture of Arthrobacter JG-9. The organism was grown in basal medium + ferrichrome to $1 \mathrm{~m} \mu \mathrm{g}$. $/ \mathrm{ml}$. After $48 \mathrm{hr}$. at $30^{\circ}$ the organisms were harvested by centrifugation and resuspended at a concentration equiv. $0.5 \mathrm{mg}$. dry wt. organism/ml. in media as follows: $O$, basal medium $+100 \mathrm{~m} \mu \mathrm{g}$. ferrichrome $/ \mathrm{ml}$; $\bullet$, basal medium + $100 \mathrm{~m} \mu \mathrm{g}$. ferrichrome $/ \mathrm{ml} .+200 \mathrm{~m} \mu \mathrm{g}$. ferrimycin $\mathrm{A} / \mathrm{ml}$; $\triangle$, basal medium $+200 \mathrm{~m} \mu \mathrm{g}$. ferrimycin $\mathrm{A} / \mathrm{ml}$.

When haemin was supplied to ferrichrome-deficient organisms, the catalase activity increased (Fig. 1). This response to haemin resembled the response to ferrichrome reported previously, and it is believed that the increased catalase activity resulted from de novo synthesis of the enzyme (Burnham \& Neilands, 1961). When haemin and ferrimycin A were simultaneously supplied to the organisms, the increase in catalase activity paralleled that obtained when haemin was added alone.

When ferrichrome was supplied to deficient Arthrobacter JG-9, catalase activity increased several fold (Fig. 2). However, when ferrimycin A and ferrichrome were added to deficient organisms simultaneously, the increase in catalase activity was markedly decreased. The control experiment with haemin and ferrimycin $\mathbf{A}$ indicated that ferrimycin $\mathbf{A}$ was not simply inhibiting catalase activity, nor was it 
inhibiting apoenzyme formation or combination of apoenzyme and haemin to form active enzyme. These results, therefore, strongly suggest that ferrimycin $\mathbf{A}$ functions as an antibiotic by antagonizing the participation of ferrichrome (sideramines) in the synthesis of haemin.

Synthesis of haemin by cell-free extracts of Rhodopseudomonas spheroides

The evidence that ferrichrome can participate in the biosynthesis of haemin was further examined in cell-free extracts of the photosynthetic bacterium Rhodopseudomonas spheroides. Resting suspensions of $R$. spheroides, incubated anaerobically in the light with $\delta$-aminolaevulate, iron citrate and an oxidizable substrate, have been shown to synthesize haemin and excrete it into the suspending medium (Lascelles, $1956 b$ ). In the present investigation, haemin formation was followed when iron was supplied as ferrichrome by using the nitrate reductase assay for haemin (Lascelles, 1956b). Results obtained using this assay were confirmed with ${ }^{59} \mathrm{Fe}$. The growth and preparation of cell-free extracts of $\boldsymbol{R}$. spheroides was as described by Lascelles (1956a). The incubation mixture contained ( $\mu \mathrm{mole} / \mathrm{ml}$.):

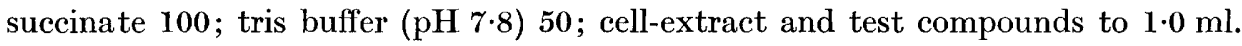
Incubation was at $37^{\circ}$ for $2 \mathrm{hr}$. under an atmosphere of $\mathrm{N}_{2}$. The reaction was

Table 1. Haemin formation by Rhodopseudomonas spheroides sonic extract

Rhodopseudomonas spheroides sonic extract $0.3 \mathrm{ml}$. (equiv. $24 \mathrm{mg}$. protein/ml.), succinate $100 \mu$ mole, tris buffer $(\mathrm{pH} \mathrm{7.8)} 50 \mu$ mole, + protoporphyrin and ferrichrome as indicated; water to $1.0 \mathrm{ml}$.; incubated at $37^{\circ}$ for $2 \mathrm{hr}$. under $\mathrm{N}_{2}$.

\begin{tabular}{|c|c|c|c|c|}
\hline \multirow[b]{2}{*}{ Tube } & \multicolumn{2}{|c|}{ Addition to incubation mixture } & \multirow{2}{*}{$\begin{array}{c}\text { Haemin } \\
\text { formed } \\
(\mathrm{m} \mu \mathrm{mole} / \mathrm{ml} .)\end{array}$} & \multirow[b]{2}{*}{$\begin{array}{l}\text { CPM/mg. } \\
\text { haemin* }\end{array}$} \\
\hline & $\begin{array}{l}\text { Protoporphyrin } \\
\qquad 10^{-3} \mathrm{M}\end{array}$ & $\begin{array}{c}\text { Ferrichrome } \\
10^{-3} \mathrm{M}\end{array}$ & & \\
\hline 1 & $0.05 \mathrm{ml}$ & - & $0 \cdot 36$ & 一 \\
\hline 2 & - & $0.05 \mathrm{ml}$. & $0 \cdot 0$ & 638 \\
\hline 3 & $0.05 \mathrm{ml}$. & $0.05 \mathrm{ml}$. & $0 \cdot 30$ & 4,820 \\
\hline 4 & $0.075 \mathrm{ml}$ & $0.05 \mathrm{ml}$. & 0.54 & 5,750 \\
\hline $\mathbf{5}$ & $0 \cdot 1 \mathrm{ml}$ & $0.05 \mathrm{ml}$ & $0 \cdot 84$ & 9,100 \\
\hline
\end{tabular}

stopped by dilution with ice water and samples removed for haemin assay with Staphylococcus aureus. Carrier haemin was added to the remainder of each sample, and haemin was crystallized three times. Radioactivity was measured in a scintillation counter.

Ferrichrome- ${ }^{-59} \mathrm{Fe}$ was prepared by mixing $1 \mathrm{ml}$. of $2 \times 10^{-3} \mathrm{M}$ iron-free ferrichrome with $0.7 \mathrm{ml}$. of $2 \times 10^{-3} \mathrm{M}^{-59} \mathrm{FeCl}_{3}$ adjusted to about $\mathrm{pH} 7 \cdot 0$ with $\mathrm{M}-\mathrm{KOH}$, and the volume was taken to $2.0 \mathrm{ml}$. The slight excess of ferrichrome insured that all of the ${ }^{59} \mathrm{Fe}$ added to the system was bound by ferrichrome.

An oxidizable substrate was required for haemin formation, presumably for reduction of the ferric iron (ferrichrome) by the extract. It is generally recognized that iron is incorporated into protoporphyrin only in the ferrous state (Paul, 1960). The haemin-forming system was dependent upon protoporphyrin and iron, and the iron could be supplied as ferrichrome. This was shown by assay with the mutant 
strain of Staphylococcus aureus and by incorporation of ${ }^{59} \mathrm{Fe}$. Ferrichrome could serve as the sole source of iron in this system (Table 1), though iron citrate was also effective.

\section{DISCUSSION}

Zähner et al. (1960) with Bacillus subtilis and Burnham (unpublished results) with Arthrobacter citreus found that haemin did not counter the action of ferrimycin A upon the growth of these organisms. If sideramines function only in the synthesis of haemin, and if sideromycins block only that reaction, then haemin should reverse the action of sideromycins on growth. Since this is not the case, one must consider additional functions for the sideramines, or, alternatively, additional sites of action for the sideromycins.

It is a pleasure to acknowledge my gratitude to Dr June Lascelles for her stimulating interest and for encouragement and patience during this work. Thanks are also due to Dr E. Vischer of Ciba Ltd., Basle, and Dr H. Zähner of the Eidg. Technischen Hochschule, Zürich, for their interest and for generous gifts of siderochromes. The skilful technical assistance of Miss Lynda Butler is gratefully acknowledged. The author was a Fellow of the Jane Coffin Childs Memorial Fund for Medical Research during this work, which was aided by a grant from this Fund.

\section{REFERENCES}

Bickel, H., Gäumann, E., Keller-Schierlein, W., Prelog, V., Vischer, E., WetTSTEIN, A. \& Z̈̈HNER, H. (1960). Über eisenhaltige Wachstumsfaktoren, die Sideramine, und ihre Antagonisten, die eisenhaltigen Antibiotika Sideromycine. Experientia, 16, 129.

Burnham, B. F. (1962). Bacterial iron metabolism: investigations on the mechanism of ferrichrome function. Arch. Biochem. Biophys. 97, 329.

Burnham, B. F. \& Neilands, J. B. (1961). Studies on the metabolic function of the ferrichrome compounds. J. biol. Chem. 236, 554 .

Emery, T. \& Nemlands, J. B. (1959). The iron-binding centre of ferrichrome compounds. Nature, Lond. 184, 1632.

Greenberg, J. \& Barker, H. A. (1962). A ferrichrome-requiring Arthrobacter which decomposes puromycin aminonucleoside. J. Bact. 83, 1163.

Hesseltine, C. W., Pidacks, C., Whitehall, A. R., Bohonos, N., Hutchings, B. L. \& Wruliams, J. H. (1952). Coprogen, a new growth factor for coprophylic fungi. J. Amer. chem. Soc. 74, 1362.

LASCElies, J. (1956a). The synthesis of porphyrins and bacteriochlorophyll by cell suspensions of Rhodopseudomonas spheroides. Biochem. J. 62, 78.

LASCELLES, J. (1956b). An assay of iron protoporphyrin based on the reduction of nitrate by a variant strain of Staphylococcus aureus; synthesis of iron protoporphyrin by suspensions of Rhodopseudomonas spheroides. J. gen. Microbiol. 15, 404.

Lochhead, A. G., Burton, M. O. \& Thexton, R. H. (1952). A bacterial growth factor synthesized by a soil bacterium. Nature, Lond. 170, 282.

NeIlands, J. B. (1952). A crystalline organo-iron compound from the fungus Ustilago sphaerogena. J. Amer. chem. Soc. 74, 4846.

Paul, K. G. (1960). Heme compounds in enzyme catalysis. In The Enzymes, 2nd ed., vol. 3, ed. by P. D. Boyer, H. Lardy and K. Myrback. New York: Academic Press.

Weil-Malherbe, H. \& Schade, R. (1948). Studies on the liver catalase of normal and cancerous rats. Biochem. J. 43, 118.

Z̈̈̈nNer, H., HütTer, R. \& BachmanN, E. (1960). Zur Kenntnis der Sideromycinwirkung. Arch.f. Mikrobiol. 36, 325. 